\title{
Do destoante ao destoado: os deslocados. A literatura infantil de Clarice Lispector
}

\author{
Flávia Alves Figueirêdo Souza *
}

\begin{abstract}
Resumo
$\mathrm{O}$ artigo investiga as especificidades da literatura infantil produzida por Clarice Lispector e analisa as obras Quase de verdade, A vida íntima de Laura, A mulher que matou os peixes e $\mathbf{O}$ mistério do coelho pensante à luz de uma série de diálogos estabelecidos entre o discurso literário e as propriedades de sua literatura infantil, desde a inserção que promove na condição de "travessia" entre a literatura infantil tradicional e a literatura infantil surgente. Analisa a natureza genuinamente híbrida por que se caracteriza; a autonomia dada à sua dimensão vocabular; a série de procedimentos aporéticos que os compõem; bem como o pacto de suspensão da realidade e de confiança que achega emissor-autor aos recebedores-leitores e os habilita para a "quase" verdade dessas histórias.

Palavras-chave: Literatura. Literatura infantil. Travessia. Clarice Lispector.
\end{abstract}

Este trabalho investiga as especificidades da literatura infantil produzida por Clarice Lispector e analisa as obras Quase de verdade (1978), A vida íntima de Laura (1974), A mulher que matou os peixes (1968) e O mistério do coelho pensante (1967) à luz de uma série de diálogos estabelecidos entre o discurso literário e os discursos de ordem histórica, filosófica, psicanalítica, pedagógica e estética.

Parece-me que a literatura infantil é um gênero de um só corpo em que vivem as mais profundas incongruências; definir a literatura infantil dependerá da singularidade do olhar a lhe ser lançado e da comunicação que esse olhar estabelecerá com outras instâncias discursivas. Conforme Marc Soriano:

a literatura infantil é uma comunicação histórica (localizada no tempo e no espaço) entre um locutor ou um escritor-adulto (emissor) e um destinatário-criança (receptor) que, por definição, ao longo do período considerado, não dispõe senão de modo parcial da experiência do real e das estruturas linguísticas, intelectuais, afetivas e outras que caracterizam a idade adulta. (SORIANO apud COELHO, 2000, p. 30-31).

Universidade Estadual de Montes Claros - UNIMONTES. 
Quando há um lado que necessita do saber possuído por outro polo, abre-se a relação de dependência, bem como todas as dificuldades desse tipo de relação. Quando o instrumento mediado é a literatura, o texto literário, ele se submete a esse intuito, e se desorienta, se perde em favor de outros propósitos menos fundamentais e bastante problemáticos.

A propósito de meu objeto, a análise dos textos de Clarice Lispector resulta em uma literatura infantil em que se alicerça um espaço de tensão, de deslocamento e de harmonização entre duas instâncias e as que lhes forem consequentes. Tratase de um ponto movediço que acontece sobre a travessia entre o tradicional e o moderno; entre a renovação e a permanência dos aspectos instaurados pela tradição europeia e com a qual dialoga a escritora. Seus textos se distinguirão das demais manifestações de linguagem, tanto à luz da diferencialidade com que suas histórias são contadas, quanto à relação peculiar que estabelece com a tradição da literatura infantil e com o contexto em que se insere. Nesse sentido, há um conjunto de operações previstas nessas obras de Lispector que se destoam dos elementos tradicionais da literatura infantil, sem que deles, contudo, se desvinculem totalmente.

A literatura de Clarice Lispector para adultos é consagrada pela sondagem das regiões mais profundas da condição humana. Trata-se de um estilo literário mais referente à reflexão, à busca e aos questionamentos empenhados pelas personagens, e menos pela complexidade de seus enredos. $\mathrm{O}$ estilo clariceano de fazer literatura é estranho. Nesse sentido, conforme Carlos Ceia, no Dicionário de termos literários, o estranhamento é um termo próprio do Formalismo Russo que se refere à finalidade da arte de dar uma sensação do objeto como visão e não como reconhecimento; o processo da arte é o processo da singularização dos objetos que obscurece a forma, a fim de aumentar a dificuldade e a duração da percepção. O estranhamento é um "efeito especial" criado pela obra de arte literária para distanciar (ou estranhar) aquele que a contempla, em relação ao modo comum como se apreende o mundo. Trata-se de uma espécie de passe-livre para uma nova dimensão, apenas adquirido pelo olhar estético ou artístico livre das amarras da linguagem trivial. A literatura de Clarice Lispector alarga a visão medíocre e ordinária com a qual se percebe o mundo, e a ascende. Isso se dá através de três operações de estranhamento: a) sobre a linguagem, b) sobre o conteúdo e c) sobre as formas literárias. Seus textos se deslocam e deslocam aos leitores: não se comprometem com a estrutura, não têm começo, meio e fim, ou linearidade; os enredos se fragmentam dando destaque a uma série de investigações que são plantadas ao longo do texto e que não se resolvem no final, não se fecham na 
última página. É um estilo incômodo que desautomatiza o lugar-comum das ideias de quem lê, de modo que uma descoberta constantemente se inaugura, o pensamento se fortalece e um mundo acontece.

O estilo clariceano de fazer literatura infantil se caracterizará pela lida especial de seus textos com a estrutura dialógica, uma vez que se alicerçará sob o diálogo íntimo e direto com seu recebedor, a partir de um contrato de confiabilidade previamente firmado entre ambos. À luz do estranhamento que sua literatura provoca na linguagem, a autonomia vocabular é redirecionada, bem como a significação de cada vocábulo, cada alcunha e de cada título que ascende ao status de propositalidade trabalhada. Lançam-se neologismos, onomatopéias e prefixações que as palavras formam, dando-lhes uma relevância significativa adequada, aporética.

Onde se lê Quase de verdade, lê-se "faz-de-conta". O vocábulo "quase" funciona como um código autorizador de uma literatura nem tão fidedigna à verdade, à realidade, à linearidade narrativa, nem totalmente mágica, inventiva, fantasiosa. A literatura infantil de Clarice Lispector traz um processo de fabulação tão envolvente que o dito real se mistura constantemente ao puramente imaginário. O título inusitado é uma premissa, a firmação de um pacto ficcional entre escritor e leitor. Declarados suspensos da realidade, emissores e recebedores se apegam ao "quase" para que se desloquem ao universo de um quintal mágico, sob a ótica de um cachorro narrador. Diferentes de Quase de verdade, A vida íntima de Laura e $\mathbf{O}$ mistério do coelho pensante levam alcunhas autoexplicativas sobre as histórias que serão contadas, ao passo que A mulher que matou os peixes pareceme mais um título-convite ao desvendamento de uma incógnita central: mas que mulher é essa? Esse livro, embora também conte histórias sobre os animais, é o mais destoado entre as obras, delas se distanciado, pois enquanto que as demais primam pelo protagonismo e pela preservação dos "animais-personagensfalantes-pensantes", especialmente os coelhos e as galinhas, A mulher que matou os peixes é a história da inabilidade da narradora quando destinada a essa tarefa. Desse modo, a literatura infantil de Clarice Lispector é, antes de tudo, uma alegoria maior da celebração da vida acontecendo, de uma rede de acontecimentos procriados, da força e dos perigos da fantasia e das ideias férteis que povoam as cabeças pensantes e que disparam sob a incitação de um só gatilho. Sua literatura infantil está gestando: um ovo-pensamento é constantemente botado e a todas as coisas movimenta.

O comportamento das personagens é direcionado por uma espécie de sopro inicial que a todos perpassa e que os destina a cada natureza, e ao estado de 
conformação dentro dessa natureza. Há uma natureza de coelho, de gente, de galinha. Nesse sentido, sobre a natureza do coelho, a narradora de $\mathbf{O}$ mistério do coelho pensante explica:

Coelho tem muita dificuldade de pensar, porque ninguém acredita que ele pense. E ninguém espera que ele pense. Tanto que a natureza do coelho até já se habituou a não pensar. E hoje em dia eles todos estão conformados e felizes. A natureza deles é muito satisfeita: contanto que sejam amados, eles não se incomodam de ser burrinhos. (LISPECTOR, 1999, s.p).

O Pequeno Dicionário Brasileiro da Língua Portuguesa define que: 1) a natureza se refere a tudo aquilo que tem como característica fundamental o fato de ser natural: ou seja, envolve todo o meio ambiente que não teve intervenção antrópica. 2) Natureza corresponde ao mundo material e, em extensão, ao universo físico: toda sua matéria e energia, inseridas em um processo dinâmico que lhes é próprio e cujo funcionamento segue regras próprias. 3) Em latim, significa: surgir, gerar, a força que gera. É aquilo que surge e que se dá por nascimento. Aquilo que é e faz por nascimento segundo leis universais aplicadas a um preciso contexto. 4) Ordem ou sistema de leis que precedem a existência das coisas e a sucessão dos seres. $\mathrm{O}$ conjunto de todos os seres que compõem o universo. Essência e qualidade ínsita de um ser. 5) Também entendido como qualidade, índole, gênio, tipo, caráter de um ser. Quando usada em um discurso para se referir ao comportamento ou às características de um determinado ser, a natureza é o conjunto de elementos que fazem daquele ser aquilo que ele é, sua essência.

A natureza do coelho é a que ele se destina; a que ele veio. É o procedimento que partilha com os demais coelhos existentes e que os coletiviza, generaliza-os dentro de um grupo característico. Dito de outra maneira, a narradora de $\mathbf{O}$ mistério do coelho pensante define a natureza de coelho a partir do modo como ele é feito e de como se ajeita na vida. Joãozinho não pensa tão fecundamente como as pessoas, é meio lento, bobo; entretanto, sua natureza o habilita para a procriação de muitos filhotes, superando a natureza dos humanos de ter menos filhos do que os coelhos. Joãozinho pertence a um grupo de coelhos também qualificados para adivinhar as coisas que lhe fazem bem, sem que alguém lhe houvesse explicado antes - nesse caso, refiro-me ao instinto animal apurado pelo qual todos os bichos se orientam. O mistério do coelho pensante é também uma história de respeito às diferenças, pois embora cada qual traga uma natureza de ordem distinta, 
isso não quer dizer que a natureza do coelho seja melhor do que a nossa. Cada natureza tem suas vantagens. Vou te dizer como é que o mundo é feito. É assim: quando se tem a natureza de coelho, a melhor coisa do mundo é ser coelho, mas quando se tem natureza de gente não se quer outra vida. (LISPECTOR, 1999, s.p).

Tudo o que excede a sua ordem natural é impulsionado pelo intuito de mudança. Através do gatilho fundamental do pensamento um procedimento de busca e de investigação acontece e caracteriza o texto. Nesses textos, toda vez que um personagem se destoa de sua rotina, desarticulando-se da retidão de seu rebanho, uma literatura começa. Novos olhares são lançados sobre o marasmo habitual com o qual se acomoda na vida. Desse modo, um quintal se torna fantástico, um poleiro, inusitado; e uma gaiola, aporética. Um mundo à parte estranha-se.

Em linhas gerais, a narrativa infantil de Clarice Lispector tem um fluxo bastante espontâneo, beirando a oralidade de quem conta; tem a fluidez de uma fala improvisada e cheia de sobressaltos e a despreocupação de que algumas informações sejam suprimidas, esquecidas para que depois sejam mencionadas, recordadas em um ponto qualquer da narração. Trata-se de uma série de recursos tão recorrentes que se convertem em um estilo clariceano de fazer literatura infantil, em que os livros se tornam um instante de confiança e de restauração da comunicabilidade perdida entre emissores e recebedores. O pacto os desinveste de seu lugar comum de compreensão da realidade e os insere no lugar da fantasia, do faz-de-conta, da "quase" verdade.

Em O mistério do coelho pensante, a resultante "despretensiosa" dos escritos é desde logo declarada por Clarice Lispector. Na dedicatória desse livro, a autora se desculpa pelo texto de uso doméstico e em que todas as entrelinhas foram deixadas para a explicação oral. Trata-se de um recurso que aproxima o procedimento autobiográfico de sua literatura infantil, pois, o livro resulta de um desejo de seu filho Paulo, "uma escrita a pedido-ordem de Paulo" (LISPECTOR, 1999, s.p) de que uma história seja contada e do intuito clariceano de fazer uma discreta homenagem a dois coelhos que pertenceram a seus dois filhos, Paulo e Pedro. Nesse sentido, a narradora se torna habilitada para uma escrita sincera e afetiva, pois declara seu intuito real de escrever para um recebedor infante, a partir da convivência e da experiência que tem com ele. Desse modo, a credibilidade que passa a assumir já suplanta a possível desqualificação por que se desculpa.

Em todos os livros há um tom aconchegante e maternal por parte de quem narra, pois, antes de tudo, a literatura infantil se transforma em um lugar preparado para acomodar o leitor, uma espécie de pacto de afeição e de aconchego que une 
emissor e recebedor na literatura de Clarice. Essa atmosfera carinhosa se dá em diferentes momentos de sua literatura infantil: em A vida íntima de Laura, passagens como "Dou-lhe um beijo na testa se você adivinhar", ou "eu estou adivinhando você." (LISPECTOR, 1999, s.p), por exemplo, dão a impressão de uma história a ser contada ao pé do ouvido. N'O mistério do coelho pensante, Paulo é o vocativo por que respondem todas as crianças leitoras, e é por conta dele (e delas) que essa história é contada. O que parece um propósito desimportante, não é. Os recebedores são alçados à categoria de responsáveis pelo surgimento de uma literatura, Clarice Lispector se rende a todos eles, os considera profundamente quando resolve contar a história do coelho Joãozinho. É o único dos livros que nomeia um recebedor. Entretanto, a afeição que se estabelece entre quem narra e quem lê é percebida de outras maneiras no decorrer das narrativas de literatura infantil. Além de incluir os recebedores no fluxo de suas histórias, os narradores de Clarice Lispector se colocam como integrantes desse grupo, assumindo sua falibilidade, compartilhando os seus anseios e seu processo de busca, "quando eu era do tamanho de você, ficava horas olhando para as galinhas. Não sei por quê. Conheço tanto as galinhas que podia nunca mais parar de contar. (...) assim a gente nunca se sente só." (LISPECTOR, 1999, s.p), conta a narradora n“A vida íntima de Laura.

Em O mistério do coelho pensante, a narradora sugere que se trate de uma história real, no sentido de que ela tenha realmente acontecimento e agora seria contada em forma de texto: "mas acontece que esta história é uma história real." (LISPECTOR, 1999, s.p) conta, ao explicar para Paulo a mediocridade da ideia tida pelo coelho. Parece-me que esse pressuposto não anula o pacto do faz-deconta, uma vez que se trata mais de uma história impulsionada pela experiência real que ganhou rumos próprios e se enveredou pelos caminhos da fantasia, ou seja, se descomprometerá com o procedimento fidedigno de se contar uma "história de verdade". O mistério do coelho pensante é a literatura que se permite depois da fuga do coelho, espaço de pura liberdade imaginativa, especulação.

Se os desarticulamos de seus ornamentos criativos, os livros de literatura infantil de Clarice Lispector tratarão de histórias conteudisticamente simples. Entre as obras, $\mathbf{O}$ mistério do coelho pensante é o livro de enredo mais sinóptico ao contar a história do coelho Joãozinho que consegue fugir de sua gaiola. Em princípio o bicho sai apenas quando está com fome, mas toma gosto pela situação e passa a fazê-lo descriteriosamente. Não se sabe como o coelho foge, há apenas especulações sobre o que ele faz livre das grades de sua casinhola. O enredo é declaradamente um convite a uma pergunta que não se fecha: como foge esse 
coelho? O mistério do coelho pensante é o próprio procedimento aporético. Por aporia, entende-se: “caminho inexpugnável, 'sem saída'. Dificuldade, impasse, paradoxo, momento de autocontradição que impede o sentido de um texto ou de que uma proposição seja determinada.” (MASSAUD, 1978, 26 p). A libertação da casinhola de suas ideias o transportou para a liberdade além das grades em que fora aprisionado. $O$ mistério do coelho pensante é uma história sobre o afã de ser livre, e de sê-lo por conta de seu próprio esforço de pensamento.

Já A vida íntima de Laura é uma das muitas produções de Clarice cujas personagens são galinhas. Neste caso, ela nos apresentará a galinha de nome Laura e sua intimidade será vasculhada. Desse modo, o mecanismo por que se empenha a investigação é a busca pela vida íntima de uma galinha. Enquanto o leitor conhece Laura, conhecer-se a si mesmo se torna um convite. Entre as obras que compõem a literatura infantil de Clarice, parece-me que essa é a que mais conta histórias dentro de uma história. Estruturalmente, os pequenos enredos são mais numerosos, todavia simples, por vezes não se fecham, tampouco se intercalam ou estabelecem o propósito de se comunicarem entre si. Há mais o que chamo de uma narrativa desconexa e fragmentada formadora de uma meta-narrativa, pois, apesar de não se imbricarem, deságuam em um mesmo fim. Há uma meta-história a ser contada sobre Laura que resulta da reunião de pequenas histórias medíocres acumuladas. O prazer dessa leitura reside no compartilhamento de uma observação, na especulação de uma vida galinácea acontecendo, de uma vida que se conta. A vida íntima de Laura é um livro marcado pela mescla da incitação proposta pelo intuito investigativo com o pacto de afetividade e de comunicabilidade que Clarice estabelece com os recebedores infantis. Trata-se de uma literatura que dá e toma, morde e assopra, acarinha e se afasta, explica, mas não se fecha. Laura é uma galinha simples, torpe, feia, mas simpática. Ela vive no quintal da Dona Luísa e é casada com o galo Luís. Nesse caso, parece-me que, assim como em sua "literatura para adultos", a autonomia vocabular das palavras escolhidas por Clarice se fortalece e faz com que a palavra siga seu rumo e seja fundamental para a execução da história. Como em Quase de verdade, essas personagens comungam de uma mesma inicial em seus nomes. A letra "L" as predestina a uma dobra brusca, acentuada, perigosa. Anuncia-se uma literatura a ser contada quando se resolve investigar a vida íntima de uma galinha. Os leitores são convidados a sair do primeiro tracejo reto que grafa o "L" para escorregarem por dentro de sua curva. Nesse território e nesse " $L$ " literário, a fantasia se permitirá.

Há também o uso de sufixos em favor da formação superlativa, diminutiva e aumentativa das palavras, conferindo-lhes autoridade de significação. Expressões 
como "burríssima"; "pensamentozinhos"; "sentimentozinhos"; "coisíssima alguma"; "feinho"; "magricelo", "fofinho", entre outras aprofundam a resultante do sentido dado às coisas, as enaltece, amplifica.

A sua linguagem na literatura infantil é menos densa, todavia não é medíocre ou esvaziada, pois, através dessas histórias o leitor envereda pela sutileza e pelos detalhes colocados por Clarice, a ponto de as reflexões mais profundas virem à tona. Por exemplo, em A vida íntima de Laura e também em Quase de verdade, a simbologia do ovo é uma constante. Penso que se o ovo representa a origem de todas as coisas, a geração da vida, sua estabilidade equivalerá a sua preservação; o mesmo cuidado que se tem com o ovo, se tem com a vida, com Deus e com a ordem natural de todas as coisas. Oniria, Ovídio, Odissea, Oquequê, Onofre, Oxalá: todas as personagens que fazem parte dessa invenção, dessa "quase" verdade, salvo a figueira anônima, são nomeadas a partir de dois aspectos: a letra "O" que os predestina e os generaliza como elementos comuns que partilham a vida, seguido da segunda parte por eles escolhido, o que marca a sua individualidade e autonomia, sua identidade e o senhorio de que a vida seja trilhada à sua maneira. Além dessa leitura, os nomes revelam o processo de intertextualidade que perpassa a narrativa em Quase de verdade. Em "Clarice, Ulisses e a figueira", Duanne Ribeiro assinala algumas referências mais óbvias:

"Oniria" remete a "onírico", ao sonho, ao criado, ao imaginário assim como a história de Ulisses, para quem "gosta de inventar". De primeira vista, posso destacar referências à literatura: Ovídio, poeta romano; Odisseia, obra de Homero (cujo protagonista é Ulisses; e Ulisses é obra de James Joyce). A continuar nesse raciocínio, eu teria de achar um referente para Onofre - o que não consegui. O nome só é o mesmo de Santo Onofre, um eremita que sobreviveu a tentações e recebeu a comida das mãos de um anjo. Esse referente, apesar de longínquo, é coerente: na história, haverá a tentação e o alimento será dado por uma benção. (RIBEIRO, 2010).

Em Quase de verdade, Ulisses é um cachorro, a sua dona se chama Clarice. Ulisses é o narrador-cachorro-personagem da história, a partir de seu ponto de vista, os leitores são convidados a conhecer um pouco mais da vida dos outros animais, plantas, das pessoas e inclusive do próprio cão. Basicamente, a história acontece em um quintal-mundo, alçado ao status de universo paralelo ao de verdade. No quintal onde os animais conversam à sua maneira, há uma figueira infrutífera que sente inveja das galinhas que botam ovos. Tramando enriquecer- 
se à custa dos outros, a figueira contatou a nuvem preta que era uma bruxa má, chamada Oxelia. A figueira é anônima, pois a ela não fora dado o dom da escolha pela criatividade, pela vontade, assim como o seu ventre é infrutífero, a sua mente só será povoada de pensamentos medíocres. Incapaz de gerar algo, ela roubará a criação das galinhas. A vilã de Quase de verdade é anônima, ingênua, infrutífera e invejosa. Diferente de um auxiliar mágico no conto de fadas tradicional, a bruxa Oxelia intervém a partir da solicitação e da iniciativa da figueira. Ainda que decorrente de um pensamento ordinário, os caminhos a serem trilhados pelas personagens, não serão determinados pela intervenção mágica, pois, servirão em segundo plano, a partir do desejo das personagens. Duanne Ribeiro segue naquilo que denomina de "análise insegura dos nomes" em Quase de verdade:

Podemos notar que a letra X no nome dá ambiguidade à "Oxelia" - como se lê? Ocsélia, Ossélia, Ochélia ou Ozélia? Ou, mais fácil, retirando a partícula "O", que é comum a todos, teremos Célia ou Zélia? A fração da individualidade que é escolha da bruxa é, deliberadamente, uma incógnita. (RIBEIRO, 2010).

Desse modo, a parte que cabe aos caminhos que serão enveredados pela nuvem bruxa é desconhecida, pois, depende da vontade de outro, das magias solicitadas pelos outros, como o desejo da figueira sem nome. Oxelia é uma nuvem que paira sem rumo no céu, é uma nuvem escura, carregada "era tão ruim que era nuvem que nem chover chovia." (LISPECTOR, 1999, s.p). Oxelia é uma fumaça preta carregada de rancor e de maldade, é um tumor da ruindade que paira sobre o quintal-mundo. A bruxa era tão ruim que queria o mal de todos, inclusive da própria figueira a quem se aliara.

O mesmo raciocínio se valida em um dos enredos d'A vida íntima de Laura que se dá sob a alcunha de "uma coisa muito bacana" a ser contada. Na ocasião, um habitante de Júpiter visita o poleiro em que Laura vive. De um só olho no meio da testa e da estatura das galinhas, filho de Xexta, o extraterrestre se chamava Xext. Nesse trecho, é possível que se incorra no terreno periclitante da dimensão vocabular atribuída à autonomia da escolha das palavras. Refiro-me, assim como o nome dado à bruxa-nuvem-do-mal Oxélia em Quase de verdade, em que o traçado "X" é utilizado sempre que se quer dar um tratamento duvidoso, imprevisível, desconhecido às personagens. A alcunha Xext, ou se desembaralho as letras "ET XX" transmite o valor incógnito de sua significação tal como a matemática o considera, o extraterrestre se apresenta a Laura enquanto os demais dormiam, 
temendo ser confundido com um fantasma. Xext é um mistério, um forasteiro que surge à luz das mil possibilidades de pronúncia tão próprias à letra " $X$ " quanto ao que vem de fora e é inábil para aos costumes locais. Conforme uma entidade mágica que intervém na fantasia, o et Xext é convertido à natureza de gênio, de bruxa ou de fada, pois oferece a possibilidade de realização de um pedido feito por Laura que deseja: "- Ah, disse Laura, se meu destino for ser comida, eu queria ser comida por Pelé!” (LISPECTOR, 1999, s.p). Desejar ser comida pelo Pelé é o modo como Laura abranda a mediocridade de sua vida, alçando-se ao universo da fama, da glória e do reconhecimento.

Estruturalmente, a narrativa de Quase de verdade se alterna em dois eixos principais: há uma história a ser contada por Ulisses sobre sua viagem ao quintalmundo; e há uma série de procedimentos que procrastinam o cumprimento dessa primeira história principal, em favor de pequenas intervenções informativas feitas pelo próprio Ulisses. Inicia-se com o chavão "era uma vez", que retoma toda a tradição convencionada pelos contos de fadas, ou seja, desde logo, o recebedor é avisado de que os procedimentos do faz-de-conta aparecerão de alguma maneira no livro. Em seguida, lê-se "era uma vez: eu!", o que rompe a exclusividade do faz-de-conta aos moldes tradicionais. O mesmo acontece com o reino que é um quintal, com o rei e a rainha que são galos e galinhas e com bruxas do bem e do mal que são nuvens. "Eu" é Ulisses, um cão que dialoga diretamente com o seu recebedor. Há uma cumplicidade essencial à efetivação da literatura infantil, o recebedor é convidado a adentrar-se na história, do mesmo modo como o narrador sai da história e dele se achega. Uma atmosfera de familiaridade se dissipa. Parece-me que há uma terceira instância que não o espaço da emissão e o espaço da recepção, mas o espaço da ficcionalização em que eles se encontram, que são movediços, atravessantes, próximos, cúmplices.

O cão Ulisses investiga tudo com o focinho, tal como o coelho Joãozinho fareja e a galinha Laura bica - esses são os mecanismos zooliterários de sua investigação. Em Quase de verdade a alegria tem cor e som, os ovos se quebrando se assemelham ao som das jabuticabas pisadas. Além disso, há a conduta do fazde-conta, além da elevação das coisas comuns ao status mágico. Acredito que tanto o recurso sinestésico quanto a elevação do habitual ao status de extraordinário são bem aceitos pelos recebedores no que toca a sua habilidade de abertura a todas as coisas.

Em A mulher que matou os peixes, a narradora confessa dois crimes: o homicídio de dois peixinhos vermelhinhos e a inabilidade assumida a que se rendeu. O texto é um pedido de perdão, é um convencimento do merecimento do 
perdão por parte de seu recebedor. Entretanto, há uma série de aspectos em que se destoa das demais obras: se a celebração da vida acontecendo é a história maior a ser contada na literatura infantil de Clarice Lispector, em A mulher que matou os peixes, o crime da narradora reside na culpa trazida pela responsabilidade de interrupção de uma vida em acontecimento. Trata-se de uma afronta à ordem natural das coisas, outrora tão primada nas outras histórias. É como se Clarice tivesse deixado que o "ovo - acontecendo" caísse de suas mãos. A literatura passa a ser um argumento em favor da desculpa desejante, que necessita de seu recebedor. Entre as obras, A mulher que matou os peixes é a que mais subverte o lugar-comum da emissão e do recebimento da literatura infantil. A falibilidade é o calcanhar-de-aquiles da personagem Clarice, ao passo em que admite o crime cometido, subjuga-se a sua condição de comando, de totalidade, apequena-se. O homicídio dos peixes é um processo de desequilíbrio da natureza, de afronta a Deus equivalente, por exemplo, à ideia ruim da figueira em Quase de verdade de estremecer o equilíbrio natural das coisas, o ponto de manutenção da vida do ovo, o senso comum a que não se ameaça e a que não se combate ou desobedece. Toda uma retidão que não se discute ou em que se intervém.

Ulisses comenta: Assim corria a vida. Mansa, mansa. Os homens homenzavam, as mulheres mulherizavam, os meninos e meninas meninizavam, os ventos ventavam, a chuva chuvava, as galinhas galinhavam, os galos galavam, a figueira figueirava, os ovos ovavam. E assim por diante. (LISPECTOR, 1999, s.p).

Tudo estava de acordo com a normalidade, as coisas agiam conforme a sua natureza, para que foram destinadas. A criação de verbos a partir da equivalência que estabelecem com seus substantivos tanto caracteriza a atuação das coisas, quanto resume o exercício de cada qual em seu lugar. Interrompe-se a calmaria: de noite as folhas da figueira brilhavam como se fosse dia de sol, as galinhas botavam sem parar e o galo cantava o dia inteiro. A ganância da figueira anônima desafiou o rumo certo pelo qual as coisas caminhavam. Se nem o rabo de Ulisses fora cortado por Clarice, porque "cortar seria contra a natureza." (LISPECTOR, 1999, s.p), a desestruturação da colocação de ovos e do cocoricar do galo não haveria de vingar nessa história em que a figueira atua como um galho torto que se desvirtua pelos perigos de uma ideia, de uma ideia ruim. Em A mulher que matou os peixes, o empenho pelo perdão é a maior submissão da personagem, sua maior falha. Assim seu relato (não) se encerra: "Vocês me perdoam?" (LISPECTOR, 1999, s.p). 
Nas obras, a maioria das personagens são animais. Parece-me que o antropomorfismo sofrido pelas personagens principais na literatura infantil de Clarice Lispector é bastante peculiar. Há um tipo de compensação atribuído às personagens que os equiparam à natureza humana. Os bichos são dotados de mecanismos que os habilitam para o comportamento ora preservador de suas identidades genuinamente animalescas ora tipicamente humanas. As obras são povoadas por cachorros, galinhas, coelhos, baratas, gatos, lagartixas, patos, macacos enquanto personagens fundamentais de uma história a ser contada. Em Clarice, a inserção da fábula refere-se mais à ficcionalização específica que aproxima recebedores e emissores, e menos à mera figuração dos personagensbichos por trás de uma moral essencial, pois se trata de uma zooliteratura que se destaca. Seus zoo-personagens, assim como as personagens-pessoas, têm desautorizados a sua dimensão arquetípica, a sua exemplaridade e o maniqueísmo por que comumente se orientam os componentes de uma literatura infantil.

Estruturalmente, a sobreposição narrativa que compõe A vida íntima de Laura a desapega de qualquer narrativa principal. A série de micro-histórias forma a "vida muito gostosinha de Laura", ou dito de outra maneira não tão aconchegante, uma narrativa ordinária sobre a intimidade de uma vida mediana que se investiga. A (não) conclusão sobre a vida íntima de Laura novamente a reduz à luz dos sufixos diminutivos que a caracterizam: "gostosinha"; "boazinha"; "vivinha". Reafirmase também o procedimento aporético que a orienta: a vida íntima não poderá ser fechada, há um conjunto de vidas íntimas desejosas de serem partilhadas, investigadas, especuladas. Abrir-se para dificilmente fechar-se, mas desdobrar-se em favor de ramificações vindouras é um comportamento preservado por Clarice Lispector na composição de sua literatura infantil. Assim como os demais livros desse gênero, A vida íntima de Laura atua como uma superfície em que diversas discussões se abrem e se estranham sob os mais diferentes níveis.

Quando Antonio Candido assinala a nova narrativa atribuída a Clarice Lispector como menos referente à simplicidade das histórias contadas, e mais às propriedades do trabalho artístico empenhado sobre as temáticas, a esse respeito, parece-me que a literatura infantil de Clarice alça acontecimentos simples ao status de especulações profundas, ainda que com histórias estruturalmente menos complexas. Os livros não são um reduto para um final feliz ou soluções e reviravoltas mirabolantes. A estrutura tradicional da literatura infantil dá lugar a uma diversidade de acontecimentos que se sobrepõem uns aos outros, que dão voltas sob o espaço híbrido do texto. Os arquétipos se convertem em personagens controversos e próximos da realidade. Os valores do bem e do mal se deslocam de 
seus lugares-comuns. Um ovo-pensamento acontece.

Em Quase de verdade, o plano podre armado pela figueira e pela nuvem Oxelia consistia em desorientar o fluxo natural das coisas, da natureza, da vida, de Deus. De noite as folhas da figueira brilhavam como se fosse dia de sol, as galinhas botavam sem parar e o galo cantava o dia inteiro. Houve uma desestabilização do relógio biológico da natureza.

Oniria e Onofre não estavam presentes, eles haviam viajado e deixado tudo aos cuidados do preguiçoso Oquequê. Seu nome liga nenhuma coisa a coisa nenhuma. Era apático e indiferente mediante o caos em que se transformara o quintal: "esse empregado era preguiçoso e só fazia comer, dormir e namorar, sem tomar conta de nada." (LISPECTOR, 1999, s.p), conta Ulisses.

Cansados de tanta exploração, as aves se rebelaram. Seu plano foi o seguinte: certa noite assim que a figueira se acendeu, as aves voaram para cima de seus galhos e se puseram a botar os ovos lá de cima. De modo que todos eles se quebraram e apodreceram na terra, dando um prejuízo enorme à figueira. Nesse ponto, a narrativa traz novamente à tona a mobilidade do código moral: "É uma pena sacrificar tanto ovo? É, mas às vezes a gente precisa fazer um sacrifício." (LISPECTOR, 1999, s.p), explica Ulisses. Os fins justificam os meios, nesse caso, matar os ovos significa dar continuidade à vida, é preciso que se morra para que se nasça. Segundo o Dicionário de símbolos esotéricos, sacrifício é:

A ideia central de todas as cosmogonias é a do "sacrifício primordial". Invertendo o conceito, pode-se deduzir que não existe criação sem sacrifício. Sacrificar alguma coisa à qual se atribui valor equivale a sacrificar a si mesmo, e a energia espiritual conquistada dessa forma é proporcional à importância daquilo que se perde. Todas as formas de sofrimento podem ter esse sentido sacrifical, desde que sinceramente procuradas e aceitas. Os sacrifícios físicos ou psicológicos negativos - mutilação, castigo, penas severas etc. - embora constituindo degenerações do sentido sacrifical original, enquadram-se sempre dentro da busca da energia espiritual. É por essas razões que a maioria dos heróis míticos, santos da Igreja e mesmo personagens de histórias do folclore passam por tantas tribulações e sofrimentos, e inclusive por situações de extrema inferioridade, como ilustra bem a história de Cinderela. (PELLEGRINI, s/d.).

Dessa maneira, os ovos são sacrificados em favor do próprio rumo natural das coisas. Matam-se os ovos em favor da restabilização da ordem da vida. A criação 
que representa o ovo também representa a necessidade de que algumas coisas morram para que outras coisas vivam, sobrevivam.

Gananciosa, a inutilização dos ovos, a restauração da vida, representará um desperdício enorme para a figueira, uma ameaça irreversível aos seus lucros. Parece-me que é nesse ponto da narrativa que Quase de verdade mais se aproxima da relação estabelecida entre o quintal dos bichos e a sociedade/comunidade dos humanos. Uma revolução é feita pela massa escravizada das galinhas, a figueira poderosa e majoritária se desorienta não apenas pelas reivindicações e a barulheira dos galináceos, mas por estar perante a derrota do poder, através da união do povo menosprezado. Ainda que vago e generalizado, observo duas referências de proporções histórias. Parece-me haver tanto um diálogo com a luta de classes entre trabalhadores e patrões quanto com a proclamação dos direitos femininos. Ulisses conta que:

Ao mesmo tempo, Ovidio começou a cocoricar:

- Queremos a liberdade de cantar só de dia!

As galinhas cacarejavam ao mesmo tempo:

- Queremos só pôr ovo só quando decidirmos e queremos os ovos só para nós. São nossos filhos!

(LISPECTOR, 1999, s.p).

Conforme observado, os acontecimentos da história principal se encaminham para o equilíbrio inicial das coisas. Os ovos são mencionados como vida, como filhos. A figueira recorre á Oxelia, que se irrita e a ameaça "com um raio que caísse em cima de sua copa e partisse em dois o seu orgulhoso tronco!” (LISPECTOR, 1999, s.p). A destruição de sua vaidade se consolida pelo escurecimento de suas luzes, de seu brilho. Nesse ponto da narrativa, o comportamento maniqueísta se redispõe. Embora a figueira tivesse assumido a função de vilã na história, percebese, desde o começo, a frouxidão de seus valores, sua suscetibilidade ao mal e a incapacidade de criação com que grafa o próprio anonimato e que a move. "A figueira ficou boba: ela não sabia até então que não se deve ser amigo dos ruins. Então muito humilhada. Viu se apagarem as suas luzes.” (LISPECTOR, 1999, s.p). A figueira não é nem totalmente boa nem totalmente má. Entretanto, há uma sutileza nesse primeiro ensinamento moral, a ruindade não está necessariamente nas más companhias, mas na desobediência ao bem, a Deus e à vida, ao uso inapropriado do ovo e a tudo o que ele simboliza. Nesse caso, embora a figueira se mostrasse desentendida e ingênua, ainda assim fora punida impiedosamente 
por seus atos inadequados. O mal se voltou contra o próprio mal, pois fora Oxelia quem a ajudara e Oxelia quem a castigara.

Em seguida, as galinhas se viram libertadas a partir de seu próprio pensamento, de sua própria vontade. Quase de verdade é também uma história sobre a força que tem uma ideia de elevar o ser pensante a outros níveis hierárquicos e de reestruturar as relações outrora estabelecidas em comunidade. Contentes, Ovidio e Odissea organizam uma festa ao sabor de mil pirulitos. As galinhas, em vez de lamber os pirulitos, os mordem. Isso faz com que percam todos os dentes que um dia tiveram e, segundo Ulisses "é por isso que as aves não têm dentes." (LISPECTOR, 1999, s.p). Parece-me que essa passagem tanto vincula um acontecimento ao seguinte, quanto sugere um segundo ensinamento camuflado dado aos infantes: os recebedores são constantemente orientados pelos adultos a não comerem muito doce, pois seus dentes ficariam podres, quebrados, ficariam banguelas. São duas situações que se sustentam mutuamente, pois, tanto se explica o motivo de as galinhas serem desdentadas, quanto avalizam a relação entre comer doces e a degradação dos dentes, que na verdade refere-se mais às cáries e à falta de escovação adequada.

A comemoração das galinhas é inconciliável com a humilhação da figueira e com a própria celebração da vida em forma de "ovo" que em toda a narrativa se faz presente. Com o retorno de Onofre e Oniria, eles permitiram que as galinhas desdentadas se aventurassem por outras terras em busca de uma comida que não necessitasse de ser mastigada. Passearam por uma relva bem verde onde esfregavam os bicos. Entretanto tinham fome. Ovidio e Odissea recorreram a uma nuvem-bruxa-boa chamada Oxalá que as guiou mata afora e mostrou-lhes um pé de jabuticaba. Duanne Ribeiro observa a natureza do nome Oxalá:

Oxalá é a mais importante divindade do Candomblé, associado à criação do mundo e do homem, à fé. (...) Vendo tudo simultaneamente, enxergamos Jesus agindo só pela força, como a própria Oxélia - e, por outro lado, Oxalá, personagem ligada à outra corrente religiosa, perdoando, fazendo o bem puro. (RIBEIRO, 2010).

Desse modo, narrativa novamente reavalia os lugares ocupados pelo bem e pelo mal. O Deus cristão que pune a figueira corresponde ao Deus do Candomblé que a soergue. $\mathrm{O}$ bem e o mal não se dividem, mas se somam em um só corpo, alternam-se a partir de diferentes gatilhos. A partir do desejo das galinhas, Oxalá 
transforma a nuvem ruim em uma nuvem boa, fazendo com que Oxelia chova e se livre do tumor maldoso que carregara, que se converte em fertilidade. Também a pedido das galinhas Oxalá perdoa a figueira que outrora fora amaldiçoada por Oxelia.

Observo que a literatura infantil de Clarice Lispector, vez ou outra, toca com fragilidade na "menina-dos-olhos" cristã: a maleabilidade atribuída aos lugares do bem e do mal, do certo e do errado, da onissapiência e da dúvida. Ao fazê-lo, tanto abala a natureza maniqueísta da literatura infantil tradicional quanto reafirma a virulência estranha a partir da qual a comunicação se estabelece. Trata-se de um silogismo incompleto e confuso que se lança. Uma espécie de aporia instigante: em A vida íntima de Laura, por exemplo, Deus criou a galinha porque ele gosta de galinha. Se Deus não gostasse de galinha, ela não existiria. O leitor existe porque Deus o criou, logo Deus gosta desse leitor. Entretanto, por que os ratos existem? O que narra não sabe explicar o porquê.

Já em Quase de verdade, a história não se encerra e não se conclui nos limites da última página. As aves descobriram que as jabuticabas eram de comer, mas não sabiam o que fazer com seus caroços; não sabiam se engoliam ou não. Eis a questão. Há de tudo na literatura infantil de Clarice Lispector: reflete-se sobre a esquisitice que rege as relações entre as pessoas e os animais, o calcanhar-deaquiles da causa vegana, amar os bichos e/mas comê-los? Fala-se do processo de "coisificação" por que passam as galinhas, uma referência à luta de classes e a opressão do discurso minoritário, entre outros assuntos. Nessa intempérie, o assunto das jabuticabas é insistentemente retomado. Explica-se sobre o gosto azedo, mas gostoso da jabuticaba, "é uma fruta redonda e preta que só existe no Brasil.” (LISPECTOR, 1999, s.p); do barulho que se faz quando se pisa nelas e do prazer que os galos e galinhas sentiam ao fazê-lo: "a gente pisa nelas e o barulho é assim: plóqui-ti-ti, plóqui-ti-ti, plóqui-ti-ti. Os galos e galinhas se deliciaram ao pisar nelas: o barulho era gostoso, dava um arrepio bom.” (LISPECTOR, 1999, s.p).

Aos moldes clariceanos, Quase de verdade não se encerra e não se conclui nos limites da última página. As aves descobriram que as jabuticabas eram de comer, mas não sabiam o que fazer com seus caroços; não sabiam se engoliam ou não. As circunstâncias aporéticas são uma constante em Clarice. Assim encerra Ulisses:

Eu que sou cachorro, não sei o que responder às aves.

- Engole-se o não engole o caroço? 
Você criança, pergunte isso à gente grande.

Enquanto isso, eu digo:

- Au, au, au!

E Clarice entende que eu quero dizer:

- Até logo, criança! Engole-se ou não se engole o caroço?

Eis a questão.

(LISPECTOR, 1999, s.p).

Aquilo a que chamo de happy end às avessas previsto na literatura infantil de Clarice Lispector refere-se à proliferação investigativa empenhada até as últimas palavras de seus livros. Ao longo de seus textos, uma série de indagações é lançada, sem que necessariamente estejam seguidas de respostas. Quando sim, observo especulações propostas mais referentes a um convite ao pensamento, à reflexão. Em Quase de verdade, dois eixos narrativos são construídos em favor de uma história principal a ser contada e de uma estrutura procrastinadora que a prolonga, a ornamenta. Entretanto, há outro nivelamento observado para a obra, ao considerála à luz de duas histórias: uma história superficial e uma série de equivalentes desdobrados, quando esmiuçada a primeira. A literatura infantil de Clarice Lispector traz uma carapaça que abriga reflexões mais aprofundadas. Povoadas de perguntas medíocres; silogismos tortuosos e uma falsa "despretensão" de se fazer literatura. Intertextos são fincados, metáforas e simbologias são avivadas e "engolir ou não engolir o caroço" é o modo de se lançar mais uma pulga atrás da orelha, em favor da inabilidade do sujeito narrador que desconhece a resposta e o didatismo das ideias mastigadas, refinadas, prontas, partilhando a dúvida com o grupo, convidando-os ao procedimento investigativo, a uma conduta especulativa mais geral, mais esperta e fecunda, mais aporética.

\begin{abstract}
The paper investigates the specifics of children's literature produced by Clarice Lispector and analyzes the works Quase verdade, A vida íntima de Laura, A mulher que matou os peixes e $\mathbf{O}$ mistério do coelho pensante focusing a series of dialogues established between literary discourse and the properties of their children's literature, the crossing between traditional children's literature and the hulking children's literature.
\end{abstract}

Keywords: Literature. Children's literature. Crossing. Clarice Lispector 
Referências

ARIÈS, Phillippe. História social da criança e da família. Tradução de Dora Flaksman. 2. ed. Rio de Janeiro: Guanabara S.A, 1981.

BENJAMIN, Valter. Reflexões: a criança, o brinquedo, a educação. São Paulo: Summus, 1984.

BERGER, John. Animais como metáfora. Animais escritos. Suplemento Literário de Minas Gerais, Belo Horizonte, Minas Gerais, p.6-9, num. 1332, Setembro Outubro/2010.

BETTLHEIM, Bruno. A psicanálise dos contos de fadas. Trad. Arlene Caetano. 2. ed. Rio de Janeiro: Paz e Terra, 1979.

CHEVALIER, Jean, GHEERBRANT, Alain. Trad. Vera da Costa e Silva et al . Dicionário de símbolos: mitos, sonhos, costumes, gestos, formas, figuras, cores, números. 11. Ed. Rio de Janeiro: José Olympio, 1997.

COELHO, Nelly Novaes. Dicionário crítico da literatura infantil e juvenil brasileira. 4.ed. São Paulo: Editora da Universidade de São Paulo, 1995.

COELHO, Nelly Novaes. Literatura infantil: teoria, análise e didática. São Paulo: Moderna, 2000.

COELHO, Nelly Novaes. O conto de fadas. São Paulo: Ática, 1987.

COMPAGNON, Antoine. Tradição Moderna, Traição Moderna In: COMPAGNON, Antoine. Os cinco paradoxos da modernidade. Belo Horizonte: UFMG, 1999, p.10-11.

ECO, Umberto. Lector in fabula: A cooperação interpretativa nos textos narrativos. Trad. Attilio Cancian. São Paulo: Perspectiva, 2004

FERREIRA, A. B. H. Pequeno dicionário brasileiro da língua portuguesa. 11. ed. rev. e ampl. Rio de Janeiro: Editora Civilização Brasileira S.A, 1998.

HUNT, Peter. Crítica, teoria e literatura infantil. Trad. Cid Knipel. São Paulo: Cosac Naify, 2010.

JAKOBSON, Roman. Linguística e comunicação. Trad. J. Blikstein e José Paulo Paes. São Paulo: Cultrix, 1992.

KHÈDE, Sonia Salomão. Personagens da literatura infanto-juvenil. São Paulo: Ática, 1986. LAJOLO, Marisa, ZILBERMAN, Regina. Literatura infantil 
brasileira: história \& histórias. 6. ed. São Paulo: Ática, 1999, p. 123.

LISPECTOR, Clarice. A mulher que matou os peixes. Rio de Janeiro: Rocco, 1999.

LISPECTOR, Clarice. A vida íntima de Laura. Rio de Janeiro: Rocco, 1999.

LISPECTOR, Clarice. O mistério do coelho pensante. Rio de Janeiro: Rocco, 1999.

LISPECTOR, Clarice. Quase de verdade. Rio de Janeiro: Rocco, 1999.

MAGALHÃES, Cademartori Lígia, ZILBERMAN, Regina. Literatura infantil: autoritarismo e emancipação. 2. ed. São Paulo: Ática, 1984.

MANZO, Lícia. Era uma vez: EU, a não-ficção na obra de Clarice Lispector. Curitiba: Secretaria de Estado de Cultura, 2001.

MEIRELES, Cecília. Problemas da literatura infantil. 3. ed. São Paulo: Summus Editorial, 1979.

MIRANDA, Ana. Clarice Lispector: o tesouro de minha cidade. Rio de Janeiro: Relume-Dumará, 1996.

MOISES, Massaud. Dicionário de termos literários. São Paulo. 2. Ed. Cultrix, 1978.

PELLEGRINI, Luis. Dicionário de símbolos esotéricos. Rio de Janeiro. Nova Fronteira, s.d.

PERES, Ana Maria Clark. O infantil na literatura: uma questão de estilo. Belo Horizonte: Miguilim, 1999.

ROSEMBERG, Fúlvia. Literatura infantil e Ideologia. São Paulo: Global, 1984. VARIN, Claire. Línguas de fogo: ensaio sobre Clarice Lispector. São Paulo: Limiar, 2002.

VARIN, Claire. Línguas de fogo: ensaio sobre Clarice Lispector. São Paulo: Limiar, 2002. 
